\title{
Thomas B. Lawrence, Roy Suddaby, and Bernard Leca, eds.: Institutional Work: Actors and Agency in Institutional Studies of Organizations
}

\section{Citation}

Dobbin, Frank. 2010. Thomas B. Lawrence, Roy Suddaby, and Bernard Leca, eds.: Institutional Work: Actors and Agency in Institutional Studies of Organizations. Administrative Science Quarterly 55, no. 4: 673-676.

\section{Published Version}

doi:10.2189/asqu.2010.55.4.673

\section{Permanent link}

http://nrs.harvard.edu/urn-3:HUL.InstRepos:12701477

\section{Terms of Use}

This article was downloaded from Harvard University's DASH repository, and is made available under the terms and conditions applicable to Other Posted Material, as set forth at http:// nrs.harvard.edu/urn-3:HUL.InstRepos:dash.current.terms-of-use\#LAA

\section{Share Your Story}

The Harvard community has made this article openly available.

Please share how this access benefits you. Submit a story.

\section{Accessibility}




\section{Institutional Work: Actors and Agency in Institutional Studies of Organizations.}

Thomas B. Lawrence, Roy Suddaby, and Bernard Leca, eds. Cambridge: Cambridge University Press, 2009. 324 pp. $\$ 99.00$, hardcover; $\$ 79.00$, e-book; $\$ 43.00$, paper.

Institutions impose constraints on us all. In recent years the institution of the university press has constrained the publication of edited volumes, and the appearance of this particular volume might be seen as evidence against the notion that institutional constraints are real. But this is the exception that proves the rule that edited volumes cannot succeed. Lawrence, Suddaby, and Leca have brought together a set of pathbreaking essays that speak authoritatively to a single issue. How do individuals build, sustain, and transform social institutions with an eye to their own, socially constructed interests?

The concept of "institutional work" that is at the heart of this volume draws on Berger and Luckmann's, and ultimately Schutz's, insight that institutions are reproduced only through the agency of individuals. Together individuals objectivize and give meaning to institutions, and separately they choose to reproduce, amend, or replace institutions. Lawrence and Suddaby (2006) coined the term "institutional work" to describe the range of ways that people build, sustain, and change institutions. The volume's title signals a focus on organizational institutions, but the chapters refer equally to political institutions, from that of community organizing to that of the Czech post-communist state.

The guiding idea is that Dennis Wrong had it right in 1961 when he argued that sociologists suffer from an oversocialized view of "man," overestimating the force of institutional constraint and underestimating the capacity of individuals to change institutions. The volume is divided into an introduction, four theory chapters, and six empirical chapters driven by a common commitment to understanding agency in institutions through grounded theory. In the introduction the grounding is in evidence from Lawrence and Suddaby's (2006) survey of institutional studies published in three leading journals, including this one. From those studies they distilled ten ways of building institutions, six ways of maintaining them, and three ways of disrupting them. In the introduction, Lawrence, Suddaby, and Leca add three insights. One is that institutional work is about action, not outcomes, and much institutional work may go on that does not lead to desired outcomes or that has unintended consequences. People are constantly doing things to build, sustain, and tear down institutions, and we should be interested in their actions, rather than in whether they succeed. Another is that intentional action should be defined broadly, encompassing habitual actions that reproduce institutions as well as actions self-consciously designed to alter them. This goes to the issue of oversocialization, and the insight is that even when agents are replicating existing institutions, we should not treat them as unthinking dopes. The third insight is that institutional work should be seen in terms of "effort." While agents are not cultural dopes, their "effort" to influence how institutions are designed and operate is a special kind of work. 
It requires effort to recognize institutional patterns as socially constructed and to socially construct new ones.

The four theory chapters continue in the vein of inductive reasoning. Julie Battilana and Thomas D'Aunno build most directly on Lawrence and Suddaby's typology to argue that we can identify three forms of agency in institutional studies, each of which operates in institution building, maintenance, and disruption. "Iterative" agency refers to small-scale decisions that can reinforce institutions or move them in a new direction, such as choosing one institutionalized practice over another. "Practical-evaluative" agency refers to selfconscious actions to reinforce, or remake, institutions within existing ideational frameworks, such as using bricolage to bring elements of different institutionalized systems together for new purposes. "Projective" agency refers to actions designed to reimagine, or retheorize, the institutional terrain, such as challenges to taken-for-granted institutional logics.

Two of the theory contributions are grounded, respectively, in empirical material on leadership from Selznick and on political action from Saul Alinsky. Matthew Kraatz's chapter on institutional leadership distills insights from Selznick's studies to show how leaders are often the true entrepreneurs building institutions, through symbolic manipulation, by making value commitments, by creating coherence, by constructing integrity, etc. Leaders, in Selznick's world, are at the center of the process of socially constructing the meaning of institutions, whereas neo-institutional studies often focus on those who carry innovations to new settings, such as consultants and professionals. Timothy Hargrave and Andrew Van de Ven ground their theory of agency in institutions in Saul Alinsky's writings on community organizing. Nothing organizers create is completely new, and in contrast to the institutional work of leaders (as Kraatz depicts it), their work is highly interactive and dependent on others. Moving out even further from leaders, Ignasi Martí and Johanna Mair build their theory of the role of marginal groups in institutional change on observations of social entrepreneurs in developing-country povertyrelief efforts. They suggest that institutional work by marginal actors is much more subtle, and incremental, than top-down studies of institutional change might suggest. Marginal actors make changes at the margin that will bubble up to alter the logic of the system.

The chapters in the "Studies" section, which more self-consciously draw insights from empirical material, address how people create institutions, in two cases, and maintain them, in four. Charlene Zietsma and Brent McKnight show the distinctiveness of institution building in a bifurcated political environment by looking at the roles of corporations and environmental groups in creating new forestry institutions. If Kraatz's chapter shows how leaders can shape the symbolic meaning of practices when they control the message and practices of firms, Zietsma and McKnight's chapter shows how different institution building is in a contentious environment and how the consequences of conflict-ridden institution building are frequently unintended, by both sides. In the most reflexive chapter in the volume, Eva Boxenbaum and Jesper Strandgaard Pedersen study the institutionalization of the 


\section{Book Reviews}

institutional paradigm in Scandinavia, showing that entrepreneurs transformed the paradigm to accord with Scandinavian intellectual and methodological traditions, such that in "translation," the paradigm's open questions and methodological imperatives would win converts in Scandinavia.

The chapters on the maintenance of institutions point to the importance, alluded to in the chapter on Scandinavian institutionalism, of negotiating the relationship between local institutions and broader systems of meaning. Tammar Zilber explores how agents in a rape crisis center sustain legitimacy with narratives of the center's role that are reinforced by Israeli meta-narratives. Actors theorize the role of their organization in terms of broad frameworks of understanding. Christine Quinn Trank and Marvin Washington explore how actors sustain institutional legitimacy in the face of a multiplicity of external constituencies, through a study of how a business school accreditation association has managed competing demands. Skill at appealing to multiple constituencies, with multiple institutional logics, is key to sustaining legitimacy. Paul Hirsch and Sekou Bermiss show that decoupling provides a means of maintaining institutions in the face of dramatic environmental change. In the Czech transition to capitalism, state agents implement some governance innovations but adopt others only symbolically so as to maintain features of the old regime. This chapter riffs nicely on Tocqueville's depiction of France under the ancient regime and after the revolution. Paula Jarzabkowski, Jane Matthiesen, and Andrew Van de Ven also develop a theory of how agents manage competing institutional logics, showing that a public utility sustains legitimacy by drawing alternatively from logics of the market and of regulation and by combining these logics in innovative ways.

Institutional Work sets out a program for institutional research in sociology and political science by highlighting how little we understand the role of individuals in building, maintaining, and toppling institutions. Berger and Luckmann, and Marx before them, remarked that we do not invent the world around us, we inherit it and can only react to what we inherit. This volume shows how productive it can be to think of people as actively engaged in interpreting institutions and as actively choosing to reproduce some, to tear others down in part or in whole, and to create new institutions from the building blocks they find at hand. It challenges the idea that the average person is blind to the fact that human agents built today's organizational and political institutions and that human agents can reinvent them. It also challenges sociologists and political scientists to test a series of new grounded theories in new contexts, and most of all to develop their own theories of agency in institutions.

Frank Dobbin

Department of Sociology

Harvard University

Cambridge, MA 02138 


\section{REFERENCES}

Lawrence, T. B., and R. Suddaby

2006 "Institutions and institutional

work." In S. Clegg, C. Hardy,

T. B. Lawrence, and W. R.

Nord (eds.), Handbook of

Organization Studies, $2 \mathrm{~d}$ ed.

215-254. London: Sage.

Wrong, D. H.

1961 "The oversocialized conception of man in modern sociology." American Sociological Review, 26: 183-193. 